\title{
PENGARUH MODEL THINK-PAIR-SHARE DENGAN METODE MIND MAPPING TERHADAP HASIL BELAJAR MAHASISWA PENDIDIKAN MATEMATIKA
}

\author{
Lies Andriani ${ }^{1)}$, Rena Revita ${ }^{2)}$ \\ ${ }^{1)}$ Fakultas Tarbiyah dan Keguruan, UIN Sultan Syarif Kasim Riau \\ ${ }^{2)}$ Fakultas Tarbiyah dan Keguruan, UIN Sultan Syarif Kasim Riau \\ Email : lies.andriani@uin-suska.ac.id \\ Email : rena.revita@uin-suska.ac.id
}

\begin{abstract}
This research is a quasi experimental research with the design used is The Nonequivalent Posttest-Only Control Group Design. This research aims to determine whether or not differences in learning outcomes between students who learn with the model of cooperative learning type think-pair-share with the method of mind mapping, with students who learn with conventional learning. Population in this research are students of Mathematics Education Study Program of UIN Suska Riau TA.2017 / 2018. Sample in this research are students of third semester (three). The data collection technique used is test technique, observation technique, and documentation. The independent variable in this research is cooperative learning model of think-pair-share type with mind mapping method, while the dependent variable is student learning result. Data analysis technique used is test " $t$ " to see whether or not difference of student learning result. The result of research shows that there are difference of mathematics learning result between students who get cooperative learning type Think-Pair-Share with Mind Mapping Method with students who get conventional learning.
\end{abstract}

\begin{abstract}
Abstrak
Penelitian ini merupakan penelitian kuasi eksperimen dengan desain yang digunakan adalah The Nonequivalent Posttest-Only Control Group Design. Penelitian bertujuan untuk mengetahui ada atau tidak ada perbedaan hasil belajar antara mahasiswa yang belajar menggunakan model pembelajaran kooperatif tipe think-pair-share dengan metode mind mapping, dengan siswa yang belajar dengan pembelajaran konvensional. Populasi dalam penelitian ini mahasiswa Program Studi Pendidikan Matematika UIN Suska Riau TA.2017/2018. Sedangkan sampel dalam penelitian ini adalah mahasiswa semester III (tiga).Teknik pengumpulan data yang digunakan adalah teknik tes, teknik observasi, dan dokumentasi. Variabel bebas dalam penelitian ini adalah model pembelajaran kooperatif tipe think-pair-share dengan metode mind mapping, sedangkan variabel terikat adalah hasil belajar mahasiswa. Teknik analisis data yang digunakan adalah tes " $t$ " untuk melihat ada atau tidaknya perbedaan hasil belajar mahasiswa. Hasil penelitian menunjukkan bahwa terdapat perbedaan hasil belajar matematika antara mahasiswa yang mendapat pembelajaran kooperatif tipe Think-Pair-Share dengan Metode Mind Mapping dengan mahasiswa yang mendapat pembelajaran konvensional.
\end{abstract}

Kata Kunci :Model, Think-Pair-Share, Mind Mapping, Hasil Belajar Mahasiswa

Belajar merupakan suatu proses berkelanjutan dalam mencapai suatu perubahan atau pembaharuan tingkah laku dan kecakapan. Dari proses belajar, khususnya di lembaga pendidikan diperoleh hasil belajar yang menurut Suprijono (dalam Th0broni, 2012:22) merupakan pola-pola perbuatan, nilai-nilai, pengertian-pengertian, sikap-sikap, apresiasi, dan keterampilan. Hasil belajar adalah prestasi belajar yang dicapai oleh peserta didik dalam proses kegiatan belajar mengajar dengan membawa suatu perubahan dan pembentukan tingkah laku seseorang. Ranah kognitif merupakan salah satu hasil belajar yang perlu diperhatikan terutama bagi mahasiswa. Sebagaimana dijelaskan oleh Bloom (Hanafiah, 2009: 20), hasil belajar pada ranah kognitif mencakup beberapa 
kemampuan sebagai berikut: a) Ingatan atau pengetahuan (knowledge), yaitu kemampuan mengingat bahan yang telah dipelajari, b) Pemahaman (comprehension), yaitu kemampuan menangkap pengertian, menterjemahkan dan menafsirkan, c) Penerapan (application), yaitu kemampuan dalam menggunakan bahan yang telah dipelajari dalam situasi baru, d) Analisis (analysis), yaitu kemampuan menguraikan, mengidentifikasi, dan mempersatukan bagian yang terpisah, menghubungkan antar bagian yang terpisah guna membangun suatu keseluruhan, e) Sintesis (syntesis), yaitu kemampuan menyimpulkan, mempersatukan bagian yang terpisah guna membangun suatu keseluruhan, dan sebagainya, f) Penilaian (evaluation) yaitu, kemampuan mengkaji nilai atau harga sesuatu pernyataan atau laporan penelitian yang didasarkan suatu kriteria.

Namun, dari hasil studi Trends in International Mathematics and Science Study (dalam Mullis, Martin, Foy \& Arora, 2012) pada tahun 2011 diketahui bahwa prestasi matematika siswa Indonesia berada pada urutan ke-38 dari 42 negara dengan skor rata-rata 386. Sedangkan survei yang dilakukan oleh OECD pada tahun 2014 menggunakan tes Programme for International Student Assesment (PISA) menyatakan bahwa prestasi matematika Indonesia berada pada peringkat 64 dari 65 negara yang mengikuti PISA. Hal tersebut memberikan gambaran bahwa hasil belajar matematika siswa masih rendah. Hal ini sejalan dengan permasalahan yang terjadi pada mahasiswa program studi pendidikan matematika UIN Suska Riau. Hasil belajar matematika, khususnya pada mata kuliah Statistik Dasar sekitar $\pm 65 \%$ mahasiswa masih di bawah nilai ideal.

Mengingat pentingnya kesemua kemampuan dari hasil belajar tersebut harus dimiliki oleh mahasiswa, khususnya bagi mahasiswa pendidikan matematika sebagai calon guru yang nantinya akan mengajarkan kemampuan tersebut ke peserta didiknya kelak, maka perlunya suatu solusi dalam pembelajaan.

Purwanto (dalam Thobroni, 2012:34) menyatakan keberhasilan suatu perubahan dari proses belajar dapat dipengaruhi oleh beberapa faktor, yaitu faktor yang ada pada diri individu dan faktor dari luar individu yang salah satunya adalah guru/dosen dan cara mengajarnya. Dosen sebagai seorang pendidik seharusnya mampu memotivasi mahasiswa, mengaktifkan proses pembelajaran, membimbing mahasiswa, menciptakan suasana belajar yang menyenangkan dan mampu mengajak mahasiswa ikut berpartisipasi dalam proses pembelajaran. Oleh sebab itu, seorang dosen haruslah mampu merancang suatu pembelajaran agar tercipta proses pembelajaran yang menyenangkan dan mampu mengajak mahasiswa untuk berpartisipasi aktif dalam proses pembelajaran yang nantinya akan berdampak pada peningkatan hasil belajar matematika mahasiswa.

Proses pembelajaran tersebut dapat terwujud dengan menggunakan salah satu model pembelajaran yang berfungsi sebagai pedoman bagi tenaga pengajar dalam merencanakan dan melaksanakan aktivitas pembelajaran. Sesuai dengan pendapat Kosasih (2014: 11) yang menyatakan bahwa menyediakan pengalaman belajar yang beragam melalui penerapan berbagai strategi pembelajaran dan model pembelajaran yang menyenangkan, kontekstual, efektif, efisien dan 
bermakna diperlukan dalam mencapai hasil pembelajaran matematika yang efektif. Selain itu, penerapan suatu model pembelajaran juga dapat digunakan dalam meningkatkan perhatian mahasiswa agar terlibat secara aktif dan mendukung pencapaian tujuan pembelajaran. Salah satu model pembelajaran matematika yang mendukung pencapain tersebut adalah model pembelajaran kooperatif tipe Think-Pair-Share.

Think-Pair-Share merupakan salah satu tipe pembelajaran kooperatif yang merangsang aktivitas berfikir mahasiswa secara berpasangan dan berbagi pengetahuan kepada siswa lainnya (Karunia Eka Lestari, 2015:52). Sedangkan menurut Arends (dalam Trianto, 2009: 132) think-pairshare merupakan suatu cara yang efektif untuk membuat variasi suasana pola diskusi kelas. Berdasarkan asumsi bahwa pada kegiatan diskusi membutuhkan pengaturan untuk mengendalikan kelas secara keseluruhan dan prosedur yang digunakan dalam think-pair-share dapat memberi mahasiswa waktu lebih banyak untuk berpikir dan merangsang aktivitas berfikir mahasiswa untuk merespon dan saling membantu secara berpasangan.

Suprijono (dalam Thobroni, 2011:299) menyatakan bahwa Think-Pair-Share (TPS) memiliki makna Thinking, Pairing, dan Sharing yang akan dijelaskan sebagai berikut : a) Thinking, Mahasiswa diberi kesempatan untuk memikirkan ide-ide mereka tentang pertanyaan atau wacana yang diberikan oleh dosen, b) Pairing, Mahasiswa menentukan dengan siapa mereka berpasangan dengan tujuan agar mahasiswa dapat berdiskusi dan mendalami ide-ide yang telah ditemukan masing-masing mahasiswa, c) Sharing, Setelah ditemukan kesepakatan ide-ide pada masing-masing kelompok, lalu pada tahap ini ide-ide tersebut dibagikan kepada kelompok lain melalui kegiatan diskusi dan tanya jawab. Hal tersebut dimaksudkan agar dari berbagai ide-ide yang mereka temukan dapat menghasilkan satu struktur yang integratif dari pengetahuan yang telah dipelajari.

Trianto (2009:81) menyatakan bahwa tek/nik Think-pair-Share atau berpikir berpasangan berbagi merupakan jenis pembelajaran kooperatif yang dirancang untuk mempengaruhi pola interaksi serta optimalisasi mahasiswa. Hal ini ditekankan juga oleh Anita Lie (2010:57) bahwa teknik ThinkPair-Share memberi mahasiswa kesempatan untuk bekerja sendiri serta bekerjasama dengan orang lain, selain itu keunggulan lain dari teknik ini adalah optimalisasi partisipasi mahasiswa.

Menurut Nanang Hanafiah (2009:,46) langkah-langkah yang dapat dilakukan dalam model mengajar ini adalah sebagai berikut : a) Dosen menyampaikan inti materi dan kompetensi yang ingin dicapai; b) Mahasiswa diminta untuk berpikir tentang materi atau permasalahan yang disampaikan dosen; c) Mahasiswa diminta berpasangan dengan teman sebelahnya (kelompok 2 orang) dan mengutarakan hasil pemikiran masing-masing; d) Dosen memimpin pleno kecil diskusi, setiap kelompok mengemukakan hasil diskusi; e) Berawal dari kegiatan tersebut mengarahkan pembicaraan pada pokok permasalahan dan menambah materi yang belum diungkapkan para mahasiswa; f) Dosen memberi kesimpulan; g) Penutup. 
Berdasarkan uraian tersebut kegiatan pembelajaran dengan menggunakan model Think-PairShare ini diawali dengan kegiatan mahasiswa memikirkan sendiri (think) materi atau permasalahan yang diberikan oleh dosen, kemudian dalam tahap berpasangan (pair) mahasiswa bekerjasama untuk mendiskusikan jawaban yang terbaik menurut mereka. Selanjutnya tahap berbagi (share) tahap untuk mempresentasikan jawaban secara kelompok di depan kelas. Dari kegiatan-kegiatan tersebut, mahasiswa diharapkan mendapatkan ide-ide secara mandiri melalui proses diskusi berpasangan. Agar model pembelajaran kooperatif tipe think-pair-share dapat secara optimal merangsang aktivitas mahasiswa sehingga tercapai tujuan pembelajaran dibutuhkan suatu metode pembelajaran. Metode pembelajaran adalah suatu cara yang digunakan untuk mecapai tujuan pembelajaran (Wina Sanjaya, 2008). Salah satu metode pembelajaran yang dapat mendukung kegiatan berfikir serta berdiskusi agar proses berfikir dan berdiskusi tersebut dapat lebih terarah dan sesuai dengan tujuan pembelajaran adalah metode pembelajaran Mind Mapping.

Mind Mapping merupakan salah satu metode pembelajaran yang melatih kemampuan menyajikan materi pembelajaran dengan pemetaan pemikiran (Endang Mulyatiningsih, 2013:238). Sedangkan menurut Karunia Eka Lestari (2015: 76) menyatakan bahwa Mind mapping merupakan suatu pembelajaran yang membantu peserta didik mengingat suatu konsep dengan bantuan mind map (menggunakan peta konsep, pencatatan materi belajar dituangkan dalam bentuk diagram yang menurut simbol, kode, gambar, dan warna yang saling berhubungan) sehingga kedua bagian otak manusia dapat digunakan secara maksimal. Dari dua pendapat tersebut dapat disimpulkan bahwa penerapan mind mapping diterapkan guna membantu peserta didik dalam mengingat dan menyajikan kembali materi pembelajaran dengan menggunakan bantuan peta konsep. Sehingga diharapkan peserta didik benar-benar paham tentang materi tersebut.

Selain itu, dengan diterapkannya pembelajaran mind mapping tersebut, mahasiswa dapat berdiskusi aktif dalam mencari ide-ide bersama pasangannya dan membantu pola-pola dari ide -ide yang mereka temukan dalam bentuk peta konsep, pencatatan ataupun diagram dan lainnya untuk membantu daya ingat mahasiswa terhadap konsep materi yang telah mereka temukan. Salah satu langkah pembelajaran mind mapping yang mempunyai kesamaaan dengan pembelajaran think-pairshare adalah siswa dikelompokkan menjadi 2-3 orang dalam bekerjasama mencatat dan memikirkan ide penting dari materi pembelajaran serta menyajikannya (Karunia Eka Lestari, 2015:76). Berkaitan dengan hal tersebut, maka peneliti melakukan penelitian yang berjudul Pengaruh Penerapan Model Pembelajaran Kooperatif TipeThink-Pair-Share dengan Metode Mind Mapping terhadap hasil belajar mahasiswa pendidikan matematika UIN Suska Riau.

Berdasarkan latar belakang dan pentingnya peningkatan hasil belajar, maka rumusan masalah dalam penelitian ini adalah apakah terdapat perbedaan hasil belajar matematika antara mahasiswa yang mendapat pembelajaran kooperatif tipe Think-Pair-Share dengan Metode Mind Mapping dengan mahasiswa yang mendapat pembelajaran konvensional. Sehingga tujuan penelitian yang akan dicapai adalah untuk mengetahui ada atau tidak ada perbedaan hasil belajar antara mahasiswa yang 
belajar menggunakan model pembelajaran kooperatif tipe think-pair-share dengan metode Mind Mapping, dengan siswa yang belajar dengan pembelajaran konvensional.

\section{METODE}

Jenis penelitian yang digunakan peneliti adalah kuasi eksperimen dengan desain yakni The Nonequivalent Posttest-Only Control Group Design. Pada desain ini terdapat dua kelompok, kelompok pertama (kelas eksperimen) diberi perlakuan X dan kelompok yang lain (kelompok kontrol) tidak diberi perlakuan X. Setelah perlakuan selesai diberikan, kedua kelompok tersebut diberi posttest (Kurnia Eka Lestari dan Mokhamad Ridwan Yudhanegara, 2017:136). Perlakuan yang dimaksud dalam penelitian ini adalah penerapan model pembelajaran Kooperatif Tipe Think-Pair-Share dengan Metode Mind Mapping.

Penelitian ini dilaksanakan pada semester ganjil TA.2017/2018 di Program Studi Pendidikan Matematika UIN Suska Riau, tepatnya pada kelas mata kuliah Statistik Dasar. Sampel dalam penelitian ini diambil dari mahasiswa semester III dengan jumlah 4 kelas. Dari 4 kelas tersebut berdasarkan teknik purposive sampling yakni teknik penentuan sampel dengan pertimbangan tertentu (Sugiyono, 2011:124) terpilih kelas III C sebagai kelas eksperimen dan kelas III D sebagai kelas kontrol.

Selanjutnya, teknik pengumpulan data dalam penelitian ini adalah teknik tes, teknik observasi, dan dokumentasi. Instrumen yang digunakan dalam memperoleh data penelitian adalah lembar soal tes dan lembar observasi. Soal tes diberikan untuk melihat hasil belajar mahasiswa dan lembar observasi digunakan untuk melihat keberhasilan pelaksanaan proses pembelajaran.

Untuk menjawab rumusan masalah diperlukan teknik analisis data yang sesuai. Teknik analisis data yang digunakan peneliti adalah tes " $t$ ". Tes " $t$ " merupakan salah satu uji statistik yang digunakan untuk mengetahui ada atau tidaknya perbedaan yang signifikan dari dua variabel yang dikomparatifkan (Hartono, 2010:178). Akan tetapi, tes "t" bisa digunakan jika data penelitian sudah diasumsikan berdistribusi normal dan homogen (Kadir, 2015: 143).

\section{HASIL DAN PEMBAHASAN}

Peneliti memilih kelas III C dan III D sebagai sampel dikarenakan data hasil belajar sebelum perlakuan dari kedua kelas tersebut tidak terdapat perbedaan. Hasil perhitungannya sebagai berikut:

Tabel 1.

Hasil Uji Perbedaan Dua Rata-Rata Hasil Belajar Matematika Sebelum Perlakuan

\begin{tabular}{|l|l|l|}
\hline t hitung & t tabel & \multicolumn{1}{c|}{ Kesimpulan } \\
\hline 0,133 & 2,021 & $\mathrm{t}$ hitung $<\mathrm{t}$ tabel (tidak terdapat perbedaan) \\
\hline
\end{tabular}


Dari Tabel 1. terlihat bahwa mahasiswa pendidikan matematika kelas III C dan III D memiliki kemampuan awal yang sama sebelum diberikan pelakuan. Kelas III C ditetapkan peneliti sebagai kelas ekspeimen dan kelas III D sebagai kelas kontrol.

Setelah perlakuan diberikan, peneliti memberikan post tes pada kedua kelas eksperimen dan kontrol. Dari hasil post tes tersebut, dilanjutkan uji prasyarat, yakni uji homogenitas dan normalitas data hasil belajar sebelum menggunakan tes " $t$ " dalam menjawab rumusan masalah penelitian. Hasil uji homogenitas dapat dilihat pada Tabel. 2 berikut:

Tabel 2.

Hasil Uji Homogenitas

\begin{tabular}{|l|l|l|}
\hline F hitung & F tabel & Kesimpulan \\
\hline 1,002 & 2,000 & F hitung $<$ F tabel (data homogen) \\
\hline
\end{tabular}

Sedangkan hasil uji normalitas dapat dilihat pada Tabel 3.berikut:

Tabel. 3

Hasil Uji Normalitas

\begin{tabular}{|l|l|l|c|}
\hline Kelas & $\boldsymbol{X}_{\text {hitung }}$ & $\boldsymbol{X}_{\text {tabel }}$ & Kesimpulan \\
\hline Eksperimen & 4,847 & 11,07 & Normal \\
\hline Kontrol & 8,299 & 11,07 & Normal \\
\hline
\end{tabular}

Berdasarkan analisis data dengan menggunakan tes " $t$ " diperoleh hasil $t_{\text {hitung }}=2,0714$ dan $t_{\text {tabel }}$ $=2,021$ pada taraf signifikan 5\%. Dari hasil tersebut $t_{\text {hitung }}>t_{\text {tabel }}$ yang berarti $H_{a}$ diterima dan $H_{o}$ ditolak. Artinya, terdapat perbedaan hasil belajar matematika antara mahasiswa yang mendapat pembelajaran kooperatif tipe Think-Pair-Share dengan Metode Mind Mapping dengan mahasiswa yang mendapat pembelajaran konvensional.

Hasil tersebut juga diperkuat dari nilai rata-rata kedua kelas. Nilai rata-rata kelas eksperimen sebesar 68,92. Sementara nilai rata-rata kelas kontrol sebesar 57,5. Hasil ini menunjukkan bahwa mean kelas yang mendapat pembelajaran kooperatif tipe Think-Pair-Share dengan Metode Mind Mapping lebih tinggi daripada mean kelas yang mendapat pembelajaran konvensional.

Hasil dari analisis data menunjukkan bahwa penerapan model pembelajaran kooperatif tipe Think-Pair-Share dengan Metode Mind Mapping dalam pembelajaran matematika menyebabkan adanya perbedaan hasil belajar matematika mahasiswa khususnya pada mata kuliah Statistik Dasar.

\section{KESIMPULAN}

Berdasarkan hasil penelitian, dapat ditarik kesimpulan bahwa terdapat perbedaan hasil belajar matematika mahasiswa yang mendapat pembelajaran kooperatif tipe Think-Pair-Share dengan 
Metode Mind Mapping dengan mahasiswa yang mendapat pembelajaran konvensional. Hal ini didukung dari nilai mean untuk kelas eksperimen lebih tinggi daripada kelas kontrol.

Selain itu, kesimpulan diperkuat oleh hasil tes " $t$ " dimana $t_{\text {hitung }}>t_{\text {tabel }}(2,071>2,021)$. Hasil penelitian ini dapat dijadikan sebagai saran atau solusi bagi dosen/pengajar dalam meningkatkan hasil belajar matematika dengan menggunakan model pembelajaran kooperatif tipe Think-Pair-Share dengan Metode Mind Mapping.

\section{DAFTAR PUSTAKA}

Hanafiah, N. dan Suhana, C.(2009).Konsep Strategi Pembelajaran.Bandung: PT.Refika Aditama.

Hartono. (2010). Statistik untuk Pendidikan. Yogyakarta: Pustaka Belajar.

Kadir. (2015). Statistika Terapan: Konsep, Contoh dan Analisis Data dengan Program SPSS/Lisrel dalam Penelitian. Jakarta: Rajawali Pers.

Kosasih. (2014). Strategi Belajar dan Pembelajaran Implementasi Kurikulum 2013. Bandung: Yrama Widya.

Lestari, K. E. dan Yudhanegara, M. R.(2017). Penelitian Pendidikan Matematika. Bandung: PT. Refika Aditama.

Lie, A. (2010). Cooperative Learning, Jakarta: PT.Grasindo.

Mullis, I.V.S., Martin, M.O., Foy, P., \& Arora, A. (2011). TIMSS 2011: International results in mathematics. Lynch School of Education: TIMSS \& PIRLS International Study Center.

Mulyatiningsih, E. (2013). Metode Penelitian Terapan Bidang Pendidikan. Bandung: Alfabeta.

OECD. (2014). PISA 2012 results in focus: what 15-years old know and what they can do with what they know. Canada: OECD.

Sanjaya, W. (2008). Strategi Pembelajaran; Berorientasi Standar Proses Pendidikan. Jakarta: Kencana Prenada Media Grup.

Sugiyono.(2011). Metode Penelitian Kuantitatif Kualitatif dan R\&D. Bandung: Alfabeta.

Thobroni, M.(2012). Belajar dan Pembelajaran. Yogyakarta: Ar-Ruzz Media,

Trianto. (2009). Mendesain Model Pembelajaran Inovatif-Progresif. Jakarta: Kencana. 